\title{
Team Leader Selection by Using an Analytic Hierarchy Process (AHP) Technique
}

\author{
Zahraa Abed Aljasim Muhisn*, Mazni Omar, Mazida Ahmad, Sinan Adnan Muhisn \\ University Utara Malaysia/School of Computing, Sintok, Kedah, Malaysia. \\ * Corresponding author.. email: flower_882004@yahoo.com \\ Manuscript submitted November 22, 2014; accepted June 8, 2015. \\ doi: 10.17706/jsw.10.10.1216-1227
}

\begin{abstract}
One of the important elements in building effective teamwork is team leader selection. In a team, leadership is the most significant role which contributes to the success of a software project. During team leader selection, there are several criteria that should be considered for decision makers. With regard to this problem, selecting team leader can be considered as Multi Criteria Decision Making (MCDM) problem. One of the most popular techniques of MCDM that can be employed in selecting the suitable team leader is Analytical Hierarchy Process (AHP). AHP techniques consists of three key principles which are hierarchy framework, priority analysis and consistency verification. Thus, this paper presents AHP steps to select suitable team leader based on four criteria which are personality type, academic achievement, teamwork experience, and previous programming grade. Result illustrates that AHP technique can assist decision maker to effectively evaluate the alternatives in order to select suitable team leader, particularly for Software Engineering (SE) education community.
\end{abstract}

Key words: Multi criteria decision making, analytical hierarchy process, team performance, team leader selection.

\section{Introduction}

Currently, research of teamwork in software engineering education field is becoming more prevalent because software projects are mostly developed in teams [1]. In fact, more researchers in Software Engineering (SE) gaining interest to research on teamwork [2]-[4]. This is because majority of SE classes requires students to work in a team. Working in a team is a challenging task because members need to accommodate the differences of background among the team members. Therefore, teamwork problem has been claimed to be the main factors that lead to software project failure [5], [6].

Selecting the right team members in team especially the team leader is central to team success [7]. Thus, the team leader selection is the first task to carry out in order to make sure successful team performance.

Past research has shown that the team leader plays an important role in the success or failure of the team [5], [8], [9]. The selecting of capable team leader can help teams develop manageable directions and unique patterns of workflow which may save time and diminish different cultural perceptions among team members [10]. In addition, Zaccaro, Rittman and Marks [11], argued that the success of the leader in defining team directions and organizing the team to maximize progress significantly contributes to team effectiveness.

Rutherfoord [12], defined a team leader as a person who combines the team together, mediates disagreements, presides at meetings, as well as interfaces with other parts of the organization. In a study 
conducted by Palmer and Summers [13], it showed that the leadership in undergraduate engineering design teams is critical for the performance of each team. Also they stated that the wrong formation of students in a group can affect other attributes such as communication, confidence, as well as project outcome.

During team leader selection, there are several criteria that should be considered for decision makers to select which criteria that suit into which team. With regard to this problem, selecting team leader can be considered as Multi Criteria Decision Making (MCDM) problem whereby many criteria should be considered in decision making. MCDM is a discipline aimed at supporting decision makers who are faced with making numerous and conflicting evaluations [14].

One of the most popular techniques of MCDM is Analytical Hierarchical Process (AHP) technique [15]. AHP is most widely used technique in decision making due to its promising accuracy, simplicity, theoretical robustness, ability to handle both qualitative and quantitative criteria, and more importantly, its ability to measure the consistency of judgment of respondents, It is basically a suitable way for understanding complex problem by using a hierarchical structure [16, [17], [18].

Gibney and Shang [19], pointed out that the AHP technique provides an effective and convenient tool for evaluating personnel and must be incorporated into personnel selection processes in academia field.

AHP is a methodology with the broad usage that allows interaction and feedback in multiple criteria decision making systems. It takes into account of quantitative as well as qualitative methods, it combines these two into an empirical enquiry [16], [17], [20]. This uses a qualitative approach for decomposing unstructured issues into a systematic decision hierarchy. From the quantitative angle, this employs a pair wise comparison for executing the consistency test for validating the responses.

AHP has diverse applications, Vaidya and Kumar [21], provided a detailed literature review on AHP applications, over 150 applications were categorized in their study. Categories were identified on the basis of themes as well as the areas of applications. Ho [22], reviewed the applications of integrated AHP in a similar way, use of AHP combined with other techniques including SWOT, Mathematical Programming and Data Envelopment Analysis between the years 1996-2007. All of these show how versatile and capable AHP is in the decision making process [23]. AHP have been implemented in most of applications related to decision making and is currently used in the subject of evaluation and selection especially in the area of personal, engineering and education [21].

Some applications of AHP in selecting of alternatives for various purposes such as, AHP used in dean selection process in academic field [19]. Garoma and Diriba [24], describe an application of AHP for supplier selection in the banking industry. AHP was also employed for selecting the suitable leadership style [18].

This study was focused on the combination of four criteria which are personality type, teamwork experience, academic achievement and previous programming grade in selecting the most suitable team leader in educational group project because these four criteria can be measured quantitatively which one is the best and can effect on teamwork performance.

Past research has shown that personality types have an impact on team performance [25,26,27]. Omar, Syed-Abdullah and Hussin [28], added that the personality types play an important role in determining team performance in software engineering projects. Teamwork experience have significant effect on team performance [12], [20], [29]. Chen and Lin [20], added that teams with more experienced members perform better than those with less experienced members.

Moreover, academic achievement play a significant role in determining team performance in software engineering projects [1]. In this study, academic achievement refers to prior Grade Point Average (GPA), it was chosen as one of software team leader selection criteria. On the other hand, Alkadi and Beaubouef [30], pointed out that the formation of team member especially team leader must have programming skills. 
Furthermore, Tadayon [31], pointed out that the selection of team members in SE must include at least two strong programmers. In this study, the participants enrolled in Information Technology (IT) courses, and one of the important criteria to select team leader is previous programming grade.

In sum, the combination of those four criteria which are personality type, teamwork experience, academic achievement and previous programming grade are able to determine effective team members and thus, effective team leader in educational group project.

Hence, this paper discusses the AHP implementation in the area of team leader selection and describes the use of AHP in selecting the most suitable team leader based on certain criteria in educational group project teamwork.

\section{AHP Process in Selecting Team Leader}

Generally, AHP consisting of three key principles, firstly, hierarchy framework, secondly, priority analysis and finally, consistency verification [25]-[27]. In the beginning of AHP, the decision problem need to be formulated into suitable form of the hierarchical framework. It consist of three levels which are, top level represents the overall objective or goal, the middle level which represents the criteria and the final level representing the alternatives.

Once a hierarchical framework is constructed, the users are requested to create a pair wise matrix at each level of hierarchy and then compare each element with the other by using the fundamental scale for pair wise comparisons as shown in Table 1. The nine point scale developed by Saaty [34] has been accepted by most experts as a very scientific and reasonable basis for comparing two alternatives [35].

Table 1. Scale for Pair-Wise Comparisons [34]

\begin{tabular}{|c|l|l|}
\hline \multicolumn{3}{|c|}{ The Fundamental Scale for Pairwise Comparisons } \\
\hline $\begin{array}{c}\text { Intensity of } \\
\text { Importance }\end{array}$ & \multicolumn{1}{|c|}{ Definition } & \multicolumn{1}{c|}{ Explanation } \\
\hline 1 & Equal importance & $\begin{array}{l}\text { Two elements contribute equally to the } \\
\text { objective }\end{array}$ \\
\hline 3 & Moderate importance & $\begin{array}{l}\text { Experience and judgment slightly favor } \\
\text { one element over another }\end{array}$ \\
\hline 5 & Strong importance & $\begin{array}{l}\text { Experience and judgment strongly favor } \\
\text { one element over another }\end{array}$ \\
\hline 7 & Very strong importance & $\begin{array}{l}\text { One element is favored very strongly } \\
\text { over another, its dominance is } \\
\text { demonstrated in practice }\end{array}$ \\
\hline 9 & Extreme importance & $\begin{array}{l}\text { The evidence favoring one element } \\
\text { over another is of the highest possible } \\
\text { order of affirmation }\end{array}$ \\
\hline $\begin{array}{l}\text { Intensities of 2, 4, 6, and 8 can be used to express intermediate values. Intensities } \\
1.1,1.2,1.3, \text { etc. can be used for elements that are very close in importance. }\end{array}$ \\
\hline
\end{tabular}

The scale translates the pairwise comparative judgements into intensity of relative importance represented by numbers to assess the intensity of preference between two elements [34]. The judgements are entered using the numbers $1,3,5,7$, and 9 which correspond to the verbal judgements. The values of 2 , 4, 6 and 8 are intermediate values that can be used to indicate compromise values of importance between the five basic assessments.

In order to determine the relative importance of criteria to select the suitable leader, data was obtained from direct questions by experts who are effectively involved in the decision problem. In this study, questionnaire for pairwise comparison proposed by Lee and Kim [36] was adapted. This questionnaire helpful to collect data in order to assign weight to the element of the decision hierarchy.

Appendix shows questionnaire of pair wise comparison between four decision criteria, which are 1) personality, 2) academic achievement, 3) teamwork experience, and 4) previous programming grade that was considered in making selection decision of team leader. 
According to Cheng and Li [37], it was observed that AHP approach is subjective methodology and that do not necessary involve large number of expert to participate in AHP process. While Saravanan and Mahendran [38], pointed out that consulting more experts will avoid bias that may be present when the judgments are considered from a single expert.

Therefore, in this study five instructors in School of Computing (SOC), Universiti Utara Malaysia (UUM) were selected as the experts for the decision-making; the experts are responsible to evaluate the criteria with respect to their importance in achieving the overall goal.

The data collect from alternatives by using questionnaire, so as to evaluate alternatives with respect to their strengths in achieving each of criteria. The respondents of the study are targeted for undergraduate students, School of Computing (SOC), Universiti Utara Malaysia (UUM).

The three main principles of AHP can be elaborated by organizing them in a more comprehensive nine steps as described in Fig. 1 [39].

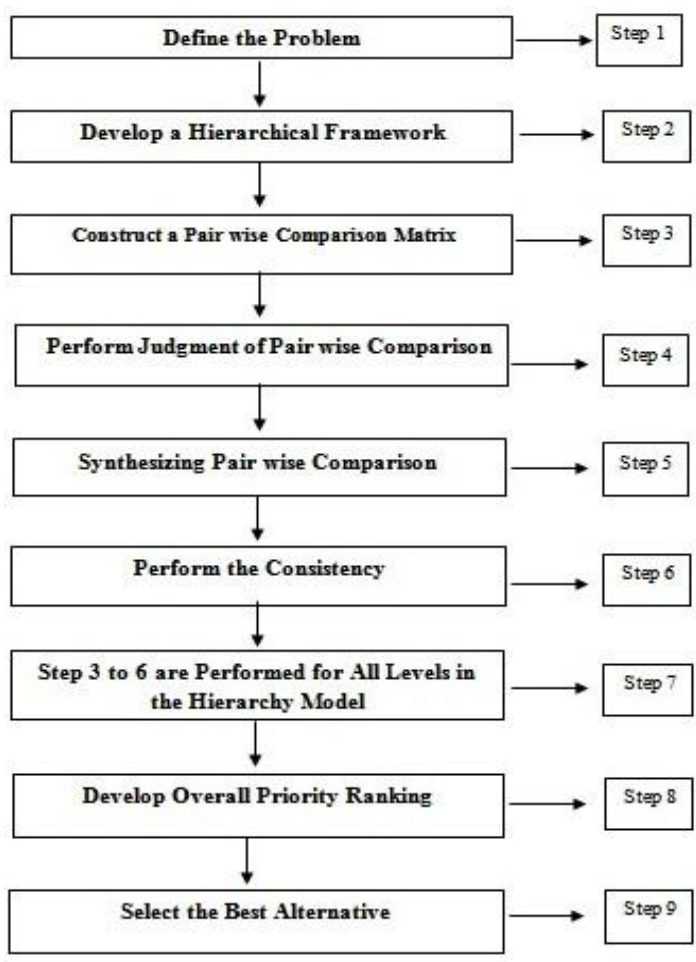

Fig. 1. Steps of AHP adopted from [39].

\section{Step 1. Define the Problem}

The research focus to select team leader in educational group project teamwork. There are four main decision criteria and four candidates in group as shown in Fig. 2. Thus, the goal is to select the suitable team leader by using AHP technique.

\section{Step 2. Develop a Hierarchical Framework}

The content and form of the hierarchy are depends on the needs and wants of the decision makers [34]. In this section, a hierarchy model for selecting the team leader using AHP technique is introduced. Fig. 2 illustrates the three level of hierarchy for decision process for this study.

\section{Level 1}

In the beginning, the goal or overall objective of the decision is showing at the first level (the top) of the hierarchy as shown in Fig. 2. In particular, the overall goal is to select the most suitable team leader based on criteria. 


\section{Level 2}

The second level represents the main decision criteria that would consider in making selection decision of team leader. These criteria determined by emanating from the discussion of literature review. The criteria divided into four aspects: personality, academic achievement, teamwork experience, and previous programming grade.

\section{Level 3}

The final level of the hierarchy represents the alternatives which are the decision option. In this study, the alternatives are the team members in educational group project teamwork. Thus, the letters (A, B, C and D) refers to the alternatives (candidates) of team members as shown in Fig. 2.

\section{Step 3. Construct a Pair Wise Comparison Matrix}

One of the most strengths of AHP technique is use pair wise comparisons to derive priorities for each criteria and the alternatives [37], [40]. These matrixes consist of $n$ columns and $n$ rows; it is a square matrix (i.e. 'A' matrix) as shown in (1). Each element of the matrix represent the preference of the factor in row $i$ to the factor in column j. All diagonal element in the matrix are (1). Also, all element in the lower triangle of the matrix can be calculated by aji $=1 /$ aij as describe in (1).

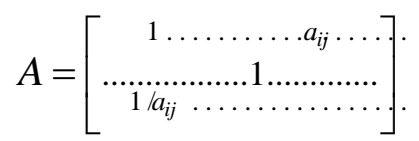

The number of matrixes at each level depends on the number elements at that level of hierarchy and the order of the matrixes at every level depending on the number of elements at the lower level that it connects to.

\section{Step 4. Perform Judgment of Pair Wise Comparison}

The decision makers should compare each element with the other by using the fundamental scale for pair wise comparisons as shown in Table 1. Pair wise comparison starts with compare between two selected elements at same level to get relative importance between them. There are $n(n-1) / 2$ judgments necessary for preparation a set of matrixes in step 3 .

To do pair wise comparison, for example as described in Table 2, if comparison between (Academic Achievement, Previous Programming Grade) and $x=3$, it means academic achievement is three time more important than Previous Programming Grade. It is automatic that $1 / 3$ or $(0.33)$ is what one needs to use in the (Previous Programming Grade, academic achievement) position.

Table 2. Pair Wise Comparison of Criteria

\begin{tabular}{|l|c|c|c|c|}
\hline \multicolumn{1}{|c|}{ Criteria } & Personality & $\begin{array}{c}\text { Academic } \\
\text { Achievement }\end{array}$ & $\begin{array}{l}\text { Teamwork } \\
\text { Experience }\end{array}$ & $\begin{array}{l}\text { Previous } \\
\text { Programming } \\
\text { Grade }\end{array}$ \\
\hline Personality & 1.00 & 4.00 & 3.00 & 7.00 \\
\hline $\begin{array}{l}\text { Academic } \\
\text { Achievement }\end{array}$ & 0.25 & 1.00 & 0.33 & $\mathbf{X = 3 . 0 0}$ \\
\hline $\begin{array}{l}\text { Teamwork } \\
\text { Experience }\end{array}$ & 0.33 & 3.03 & 1.00 & 5.00 \\
\hline $\begin{array}{l}\text { Previous } \\
\text { Programming } \\
\text { Grade }\end{array}$ & 0.14 & 0.33 & 0.20 & 1.00 \\
\hline SUM & 1.73 & 8.36 & 4.53 & 16.00 \\
\hline
\end{tabular}


Table 3. Synthesized Matrix for the Criteria

\begin{tabular}{|l|l|l|l|l|l|}
\hline Criteria & Personality & $\begin{array}{l}\text { Academic } \\
\text { Achievement }\end{array}$ & $\begin{array}{l}\text { Teamwork } \\
\text { Experience }\end{array}$ & $\begin{array}{c}\text { Previous } \\
\text { Programming } \\
\text { Grade }\end{array}$ & $\begin{array}{l}\text { Eigenvector } \\
\text { (Priority) }\end{array}$ \\
\hline Personality & 0.58 & 0.48 & 0.66 & 0.44 & 0.54 \\
\hline $\begin{array}{l}\text { Academic } \\
\text { Achievement }\end{array}$ & 0.14 & 0.12 & 0.07 & 0.19 & 0.13 \\
\hline $\begin{array}{l}\text { Teamwork } \\
\text { Experience }\end{array}$ & 0.19 & 0.36 & 0.22 & 0.31 & 0.27 \\
\hline $\begin{array}{l}\text { Previous } \\
\text { Programming }\end{array}$ & 0.08 & 0.04 & 0.04 & 0.06 & 0.06 \\
\hline Grade & 1.00 & 1.00 & 1.00 & 1.00 & 1.00 \\
\hline Total & & & & & \\
\hline
\end{tabular}

The pair wise questionnaires as shown in Appendix were given to the experts and requested to fill up by identify relative importance between four decision criteria, which are 1) personality type, 2) academic achievement, 3) teamwork experience, and 4) previous programming grade that which considered in making selection decision of team leader. All responses were collected and recorded. The data in Table 2 is based on expert's opinion.

The experts believed that a personality type is four time more important than academic achievement, and three time more important than teamwork experience, as well as seven time more important than previous programming grade respectively, due to extrovert team leader can improve performance of team in group work project. In regards to this, Omar and Syed-Abdullah [27], pointed out that an effective team needs to have more extrovert members.

Furthermore, experts thought that teamwork experience is three time more important than academic achievement, in contrast to this, they thought academic achievement is three time more important than previous programming grade. Finally, experts believed that teamwork experience is five time more important than previous programming grade in selecting suitable team leader for group project in educational setting.

Finally, this study revealed that the most important criteria to select team leader is personality types, followed by teamwork experience, academic achievement and previous programming grade.

\section{Step 5. Synthesizing Pair wise Comparison}

Saaty [34], demonstrated mathematically that the eigenvector method was the best approach to determine the priorities from each pair wise matrix in order to get importance of criteria and alternative performance.

According to Hsiao [41], the Average of Normalized Column (ANC) method is used for calculate the eigenvectors for priorities. The ANC process can be divided into three steps:

1) Sum of each column in matrix

2) Divide each elements of matrix with the sum of its column

3) Normalized principle of Eigen vector and that can be done by add the element in each resulting row and then divide this sum by the number of elements in the row $(n)$.

In a mathematical form, the eigenvector (priorities) could be calculated as described in (2)

$$
W_{i}=\frac{1}{n} \sum_{j=1}^{n} \frac{a_{i j}}{\sum_{i}^{n} a_{i j}}, i, j=1,2, \ldots \ldots \ldots . . . n
$$

Table 3 illustrates the eigenvector (priorities) for criteria. For example, to calculate the priority of 
(personality), it can be done by applying three steps as follows:

1) $\sum_{i}^{n} a_{i j}$ Thus, $1+4+3+7=15$.

2) $\frac{a_{i j}}{\sum_{i}^{n} a_{i j}} \quad$ Thus, $1 / 15=0.58$.

3) $\sum_{j}^{n} \frac{a_{i j}}{\sum_{i}^{n} a_{i j}}$ Thus, $0.58+0.48+0.66+0.44=2.16$ and divided this sum by the number of elements $(n=$

4) Thus, $2.16 / 4=0.54$.

\section{Step 6. Perform the Consistency}

Since the comparisons are performed through subjective judgments or personal, possible occurrence some of inconsistency. To ensure the judgment are consistent, the last process called consistency verification, which is considered as one of the significant task of AHP, is included to measure the degree of consistency among the pair wise comparisons by computing the consistency ratio [22].

According to Saaty [34], if the Consistency Ratio (CR) is more than 0.1 the judgment is untrustworthy due to they are close for comfort to random and the exercise is should be repeated or valueless.

There are three steps to calculate the Consistency Ratio (CR) as follows:

1) Calculation of Eigenvalue $(\lambda \max )$

$$
(\mathrm{A} X=\lambda \max \mathrm{X})
$$

where $A$ is the comparison matrix with size $n \times n, X$ is the eigenvector of size $n \times 1$.

2) Calculation of Consistency Index (CI).

$$
\mathrm{CI}=(\lambda \max -n) /(n-1)
$$

where $n$ is the size of matrix.

3) Calculation of Consistency Ratio (CR).

$$
\mathrm{CR}=\mathrm{CI} / \mathrm{RI}
$$

Determining the suitable value of Random Index (RI) from the table of random index of AHP as shown in Table 4, for the matrix size of four the random index will be RI $=0.90$, after that calculate Consistency Ratio (CR). For instance, the calculation to consistency test for the criteria $C R=C I / R I, C R=0.04 / 0.90=0.04$. As the value of CR is less than 0.1 , the judgements are acceptable.

Table 4. Random Index of Analytic Hierarchy Process [34]

\begin{tabular}{lccccccccc}
\hline Size of matrix & 12 & 3 & 4 & 5 & 6 & 7 & 8 & 9 & 10 \\
\hline Random consistency index 0 & 0 & 0.58 & 0.90 & 1.12 & 1.24 & 1.32 & 1.41 & 1.45 & 1.49 \\
\hline
\end{tabular}

\section{Step 7. Step 3 To 6 are Performed for All Levels in the Hierarchy Model}

The elements in Tables 5-8 and Table 9 illustrate the priority (eigenvector) and consistency test for the criteria and the alternatives. As all criteria and alternatives have CR value less than 0.1 , the judgements are acceptable.

\section{Step 8. Develop Overall Priority Ranking}

After complete the calculation for the consistency for all levels, more calculation for the overall priority vector to select the most suitable leader must be performed. Table 10 illustrates the overall priority of the 
four alternatives with respect to the four criteria. The overall priority (eigenvector) can be calculated by multiplying the eigenvector of the alternative by the eigenvector for the criteria, for example:

$$
(0.46 \times 0.54)+(0.44 \times 0.13)+(0.47 \times 0.27)+(0.41 \times 0.06)=0.46
$$

Table 5. The Eigenvector and Consistency Test for Alternatives with Respect to Personality

\begin{tabular}{|l|c|c|c|c|c|}
\hline Personality & A & B & C & D & $\begin{array}{c}\text { Eigenvector } \\
\text { (Priority) }\end{array}$ \\
\hline A & 1.00 & 2.00 & 3.00 & 4.00 & 0.46 \\
\hline B & 0.50 & 1.00 & 3.00 & 2.00 & 0.27 \\
\hline C & 0.33 & 0.33 & 1.00 & 0.33 & 0.10 \\
\hline D & 0.25 & 0.50 & 3.03 & 1.00 & 0.17 \\
\cline { 2 - 5 } & Consistency Ratio (CR) & 1.00 \\
\hline
\end{tabular}

Table 6. The Eigenvector and Consistency Test for Alternatives with Respect to Teamwork Experience

\begin{tabular}{|l|c|c|c|c|c|}
\hline $\begin{array}{l}\text { Teamwork } \\
\text { Experience }\end{array}$ & $\mathrm{A}$ & $\mathrm{B}$ & $\mathrm{C}$ & $\mathrm{D}$ & $\begin{array}{c}\text { Eigenvector } \\
\text { (Priority) }\end{array}$ \\
\hline $\mathrm{A}$ & 1.00 & 2.00 & 3.00 & 4.00 & 0.47 \\
\hline $\mathrm{B}$ & 0.50 & 1.00 & 2.00 & 3.00 & 0.28 \\
\hline $\mathrm{C}$ & 0.33 & 0.50 & 1.00 & 2.00 & 0.16 \\
\hline $\mathrm{D}$ & 0.25 & 0.33 & 0.50 & 1.00 & 0.10 \\
\cline { 2 - 5 } & \multicolumn{5}{c}{ Consistency Ratio (CR) } \\
\cline { 2 - 5 }
\end{tabular}

Table 7. The Eigenvector and Consistency Test for Alternatives with Respect to Previous Programming Grade

\begin{tabular}{|l|c|c|c|c|c|}
\hline $\begin{array}{l}\text { Previous } \\
\begin{array}{l}\text { Programming } \\
\text { Grade }\end{array}\end{array}$ & $\mathrm{A}$ & $\mathrm{B}$ & $\mathrm{C}$ & $\mathrm{D}$ & $\begin{array}{c}\text { Eigenvector } \\
\text { (Priority) }\end{array}$ \\
\hline $\mathrm{A}$ & 1.00 & 2.00 & 2.00 & 3.00 & 0.41 \\
\hline $\mathrm{B}$ & 0.50 & 1.00 & 2.00 & 3.00 & 0.29 \\
\hline $\mathrm{C}$ & 0.50 & 0.50 & 1.00 & 2.00 & 0.19 \\
\hline $\mathrm{D}$ & 0.33 & 0.33 & 0.50 & 1.00 & 0.11 \\
\hline \multicolumn{5}{|c|}{ Consistency Ratio (CR) } & 1.00 \\
\hline
\end{tabular}

Table 8. The Eigenvector and Consistency Test for Alternatives with Academic Achievement

\begin{tabular}{|l|c|c|c|c|c|}
\hline $\begin{array}{l}\text { Academic } \\
\text { Achievement }\end{array}$ & $\mathrm{A}$ & $\mathrm{B}$ & $\mathrm{C}$ & $\mathrm{D}$ & $\begin{array}{c}\text { Eigenvector } \\
\text { (Priority) }\end{array}$ \\
\hline $\mathrm{A}$ & 1.00 & 3.00 & 2.00 & 3.00 & 0.44 \\
\hline $\mathrm{B}$ & 0.33 & 1.00 & 2.00 & 4.00 & 0.29 \\
\hline $\mathrm{C}$ & 0.50 & 0.50 & 1.00 & 1.00 & 0.15 \\
\hline $\mathrm{D}$ & 0.33 & 0.25 & 1.00 & 1.00 & 0.12 \\
\cline { 2 - 5 } & \multicolumn{5}{c|}{ Consistency Ratio (CR) } \\
\cline { 2 - 5 }
\end{tabular}

\section{Step 9. Select the Best Alternative}

Table 11 illustrates the candidate A that has the highest value (0.46) among the other candidates. The second highest is the candidate B with a value of (0.27) and the candidate $C$ with a value of $(0.13)$ and finally, the candidate D with a value of only (0.14), candidate A is the preferred choice because it has the highest 
value among four alternatives.

Table 9. The Eigenvector and Consistency Test for Criteria with Respect to Goal

\begin{tabular}{|c|c|c|c|c|c|}
\hline Criteria & Personality & $\begin{array}{c}\text { Academic } \\
\text { Achievement }\end{array}$ & $\begin{array}{l}\text { Teamwork } \\
\text { Experience }\end{array}$ & $\begin{array}{c}\text { Previous } \\
\text { Programming } \\
\text { Grade }\end{array}$ & $\begin{array}{c}\text { Eigenvector } \\
\text { (Priority) }\end{array}$ \\
\hline Personality & 1.00 & 4.00 & 3.00 & 7.00 & 0.54 \\
\hline $\begin{array}{l}\text { Academic } \\
\text { Achievement }\end{array}$ & 0.25 & 1.00 & 0.33 & 3.00 & 0.13 \\
\hline $\begin{array}{l}\text { Teamwork } \\
\text { Experience }\end{array}$ & 0.33 & 3.03 & 1.00 & 5.00 & 0.27 \\
\hline \multirow[t]{3}{*}{$\begin{array}{l}\text { Previous } \\
\text { Programming } \\
\text { Grade }\end{array}$} & 0.14 & 0.33 & 0.20 & 1.00 & 0.06 \\
\hline & & & & & 1.00 \\
\hline & & & Consistency & atio (CR) & 0.04 \\
\hline
\end{tabular}

Table 10. Priority Vector for the Alternatives with Respect to the Criteria

\begin{tabular}{|l|c|c|c|l|c|c|}
\hline Criteria & Personality & $\begin{array}{l}\text { Academic } \\
\text { Achievement }\end{array}$ & $\begin{array}{l}\text { Teamwork } \\
\text { Experience }\end{array}$ & $\begin{array}{l}\text { Previous } \\
\text { Programming } \\
\text { Grade }\end{array}$ & $\begin{array}{l}\text { Criteria } \\
\text { Weights }\end{array}$ & $\begin{array}{l}\text { Overall } \\
\text { Priority }\end{array}$ \\
\hline A & 0.46 & 0.44 & 0.47 & 0.41 & 0.54 & 0.46 \\
\hline B & 0.27 & 0.29 & 0.28 & 0.29 & 0.13 & 0.27 \\
\hline C & 0.10 & 0.15 & 0.16 & 0.19 & 0.27 & 0.13 \\
\hline D & 0.17 & 0.12 & 0.10 & 0.11 & 0.06 & 0.14 \\
\hline
\end{tabular}

Table 11. Result of Selection

\begin{tabular}{|c|c|}
\hline Candidate & Ranking of Candidate ( Goal) \\
\hline A & 0.46 \\
\hline B & 0.27 \\
\hline C & 0.13 \\
\hline D & 0.14 \\
\hline
\end{tabular}

\section{Results and Discussion}

The results shown that the AHP technique can be used to help decision makers to evaluate and select the best alternative based on the certain criteria of a decision. The analysis illustrates that the candidate $\mathrm{A}$ is the most suitable to select as a team leader due to he/she has the highest value $(0.46)$ among the other candidate.

Application of AHP for selecting the most suitable team leader can improve performance of team in group work project in educational field due to the team leader plays an significant role in the failure or success of the team [5], [8], [9].

\section{Conclusion}

This paper presents the steps taken to select the most suitable team leader by using Analytical Hierarchy Process (AHP) technique. Four criteria which are personality type, academic achievement, teamwork experience, and previous programming grade were chosen to determine the leader in educational group project teamwork. 
The future work of this study is to develop a prototype to evaluate the suitability of AHP technique and thus, data from student's team project will be collected to evaluate the technique.

Appendix

A Pairwise Comparison between Criteria

\begin{tabular}{|c|c|c|c|c|c|c|c|c|c|c|c|c|c|c|c|c|c|c|}
\hline Criteria & 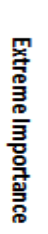 & $>$ & 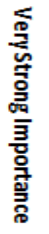 & $>$ & 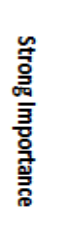 & $>$ & 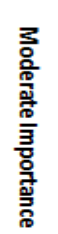 & $>$ & 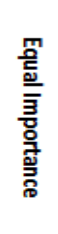 & $<$ & 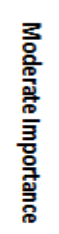 & $<$ & 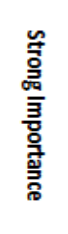 & $<$ & 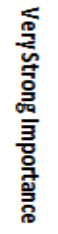 & $<$ & 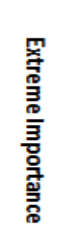 & Criteria \\
\hline & (9) & 8 & (7) & (6) & (5) & (4) & (3) & (2) & (1) & (2) & (3) & (4) & (5) & (6) & (7) & (8) & (9) & \\
\hline Personality & & & & & & & & & & & & & & & & & & $\begin{array}{c}\text { Academic } \\
\text { Achievement }\end{array}$ \\
\hline Personality & & & & & & & & & & & & & & & & & & $\begin{array}{l}\text { Teamwork } \\
\text { Experience }\end{array}$ \\
\hline Personality & & & & & & & & & & & & & & & & & & $\begin{array}{c}\text { Previous } \\
\text { Programming } \\
\text { Grade } \\
\end{array}$ \\
\hline $\begin{array}{c}\text { Academic } \\
\text { Achievement }\end{array}$ & & & & & & & & & & & & & & & & & & $\begin{array}{l}\text { Teamwork } \\
\text { Experience }\end{array}$ \\
\hline $\begin{array}{c}\text { Academic } \\
\text { Achievement }\end{array}$ & & & & & & & & & & & & & & & & & & $\begin{array}{c}\text { Previous } \\
\text { Programming } \\
\text { Grade } \\
\end{array}$ \\
\hline $\begin{array}{l}\text { Teamwork } \\
\text { Experience }\end{array}$ & & & & & & & & & & & & & & & & & & $\begin{array}{c}\text { Previous } \\
\text { Programming } \\
\text { Grade }\end{array}$ \\
\hline
\end{tabular}

\section{Acknowledgment}

The authors wish to thank Universiti Utara Malaysia (UUM) for funding this study under High Impact Group Research Grant Scheme (PBIT), S/0 project: -12867.

\section{References}

[1] Omar, M., Abdullah, S. L. S., \& Hussin, N. M. (2011). Developing a team performance prediction model: A rough sets approach. Informatics Engineering and Information Science, 691-705.

[2] Figl, K. (2010). A systematic review of developing team competencies in information systems education. J. Inf. Syst. Educ., 21(3), 323.

[3] Robillard, P. N., \& Lavallée, M. (2012). Software team processes: A taxonomy. Proceedings of the Process 2012 International Conference on Software and System (pp. 101-109).

[4] Yu, H., Bao, X., \& Yang, S. (2009). Research and improvement of team software process. Proceedings of the 2009 WRI World Congress on Computer Science and Information Engineering (pp. 654-658).

[5] Humphrey, W. S. (2006). TSP Leading a Development Team. Pearson Education. 2006.

[6] Marques, M., \& Ochoa, S. F. (2014). Improving teamwork in students software projects. Proceedings of the 2014 IEEE 27th Conference on Software Engineering Education and Training (CSEE\&T) (pp. 99-108).

[7] Rovira, N., Ozgen, S., Medir, M., Tous, J., \& Alabart, J. R. (2012). Human values in the team leader selection process. Span. J. Psychol., 15(1), 216-226, 2012.

[8] Gilley, J. W., Morris, M. L., Waite, A. M., Coates, T., \& Veliquette, A. (2010). Integrated theoretical model for building effective teams. Adv. Dev. Hum. Resour., 12.

[9] Rong, G., \& Shao, D. (2012). Delivering software process-specific project courses in tertiary education environment: Challenges and solution. Proceedings of the 2012 IEEE 25th Conference on Software Engineering Education and Training (pp. 52-61).

[10] Tseng, H., Wang, C., Ku, H., \& Sun, L. (2009). Key factors in online collaboration and their relationship to teamwork satisfaction. Q. Rev. Distance Educ., 10(2), 195-206.

[11] Zaccaro, S. J., Rittman, A. L., \& Marks, M. A. (2002). Team leadership. Leadersh. Q., 12(4), 451-483. 
[12] Rutherfoord, R. H. (2006). Using personality inventories to form teams for class projects: a case study. Proceedings of the 7th conference on Information Technology Education( pp. 9-14).

[13] Palmer, G., \& Summers, J. (2011). Characterization of leadership within undergraduate engineering design teams through case study analysis. Proceedings of the 18th International Conference on Engineering Design (ICED 11), Impacting Society through Engineering Design.

[14] Deniz, C., \& Metin, N. (2009). Using analytic hierarchy process for selecting the appropriate host country to study english language abroad. Int. J. Soc. Sci. Humanit. Stud., 1.

[15] Dalalah, D., Al-oqla, F., \& Hayajneh, M. (2010). Application of the analytic hierarchy process (AHP) in multi-criteria analysis of the selection of cranes. Jordan J. Mech. Ind. Eng., 4(5), 567-578.

[16] Khatrouch, I., Boujelbene, Y., Kermad, L., \& Elmehamedi, A. (2014). An integrated case-based reasoning and AHP method for team selection. Int. Conf. Business, Econ. Mark. Manag. Res., 2, 13-18.

[17] Jain, R., \& Rao, B. (2013). Application of AHP tool for decision making of choice of technology for extraction of anti-cancer bioactive compounds of plant origin. Int. J. Anal. Hierarchy Process, 5(1), 3-29,.

[18] Zendeh, A. B., \& Aali, S. (2011). An AHP approach for selecting the suitable leadership style. Int. Proc. Econ. Dev. Res., 25, 20-24.

[19] Gibney, R., \& Shang, J. (2007). Decision making in academia: A case of the dean selection process. Math. Comput Model.

[20] Chen, S., \& Lin, L. (2004). Modeling team member characteristics for the formation of a multifunctional team in concurrent engineering. Eng. Manag. IEEE Trans., 51(2), 111-124.

[21] Vaidya, O. S., \& Kumar, S. (2006). Analytic hierarchy process: An overview of applications. Eur. J. Oper. Res., 169(1), 1-29.

[22] Ho, W. (2008). Integrated analytic hierarchy process and its applications-a literature review. Eur. J. Oper. Res., 186(1), 211-228.

[23] Gurumurthy, A., \& Kodali, R. (2012). An application of analytic hierarchy process for the selection of a methodology to improve the product development process. J. Model. Manag., 7(1), 97-121.

[24] Garoma, T., \& Diriba, S. (2014). Modeling and analysis of supplier selection method using analytical hierarchy process (AHP). Sci. Technol. Arts Res. J., 3(1), 145-151.

[25] Acuna, S. T., Gomez, M., \& Juristo, N. (2009). How do personality, team processes and task characteristics relate to job satisfaction and software quality?. Inf. Softw. Technol., 5(3), 627-639.

[26] Capretz, L. F., \& Ahmed, F. (2010). Making sense of software development and personality types. IT Prof., 12(1), 6-13.

[27] Omar, M., \& Abdullah, S. L. S. (2010). Identifying effective software engineering ( SE ) team personality types composition using rough set approach. Proceedings of the 2010 International Symposium on Information Technology (ITSim).

[28] Omar, M., Abdullah, S. L. S., \& Hussin, N. M. (2010). Analyzing personality types to predict team performance. Proceedings of the International Conference on Science and Social Research (CSSR).

[29] Antoniadis, D. N. (20120. Complexity and the process of selecting project team members. J. Adv. Perform. Inf. Value, 4(1).

[30] Alkadi, G., \& Beaubouef, T. (2008). An experimental group for researching and developing software. J. Comput. Sci. Coll., 23(6), 104-109.

[31] Tadayon, N. (2004). Software engineering based on the team software process with a real world project. J. Comput. Sci. Coll., 19(4), 133-142.

[32] Adhikaril, I., Kim, S. Y., \& Lee, Y. D. (2006). Selection of appropriate schedule delay analysis method: Analytical hierarchy process (AHP). Technology Management for the Global Future.

[33] Cheng, S. C., Chen, M. Y., Chang, H. Y., \& Chou, T. C. (2007). Semantic-based facial expression recognition 
using analytical hierarchy process. Expert Syst. Appl., 33(1), pp. 86-95, 2007.

[34] Saaty, T. L. (1980). The Analytic Hierarchy Process. New York: McGraw Hill.

[35] Taylor, B. W. (2010). Introduction to Management Science Tenth Edition (10th ed.) (pp. 431-433). New Jersey: Pearson Education Inc.

[36] Lee, H. H., \& Kim, C. S. (2013). An analysis on the relative importance of the risk factors for the marine traffic environment using analytic hierarchy process. J. Korean Soc. Mar. Environ. Saf., 19(3), 257-263.

[37] Cheng, E., \& Li, H. (2001). Analytic hierarchy process: an approach to determine measures for business performance. Meas. Bus. Excell., 5(3), 30-37.

[38] Saravanan, S., \& Mahendran, P. (2014). An AHP based approach-selection of measuring instrument for engineering institution selection. Asia Pacific J. Res., 1, 143-150.

[39] Ariff, H., \& Salit, M. S., Ismail, N., \& Nukman, Y. (2012). Use of analytical hierarchy process (AHP) for selecting the best design concept. J. Teknol., 49, 1-18.

[40] Saaty, T. L. (2008). Decision making with the analytic hierarchy process. Int. J. Serv. Sci., 1(1).

[41] Hsiao, S. (2002). Concurrent design method for developing a new product. Int. J. Ind. Ergon., 29, 41-55.

Zahraa Abed Aljasim Muhisn holds the MSc. degree in information technology from School of Computing, College of Arts and Sciences, Universiti Utara Malaysia in 2015. Her current research interests include information system development, empirical software engineering and software engineering education.

Mazni Omar is a senior lecturer at the School of Computing, College of Arts and Sciences, Universiti Utara Malaysia. She received the BSc. degree (with honors) in information technology from Universiti Utara Malaysia, in 2000, the MSc. degree in software engineering from Universiti Teknologi Malaysia, in 2002, and the Ph.D. degree in information technology and quantitative sciences from Universiti Teknologi MARA, Malaysia, in 2012. Her current research interests include agile software development, empirical software engineering, software quality and data mining.

Mazida Ahmad is a senior lecturer at the School of Computing, College of Arts and Sciences, Universiti Utara Malaysia. She received the BMIS degree from International Islamic University of Malaysia, in 2001, the MSc. degree in software engineering from Universiti Teknologi Malaysia, in 2003, and the Ph.D. degree in knowledge management from Universiti Sains Malaysia, in 2010. Her current research interests include knowledge management, information system development and software engineering education.

Sinan Adnan Muhisn holds the MSc. degree in information technology from School of Computing, College of Arts and Sciences, Universiti Utara Malaysia in 2015. His current research interests include information system development, software engineering education, web services and elector. 